\title{
Digitising India through mobile applications - Measuring the success of the Indian Government
}

\author{
Ritu Srivastava ${ }^{1, *}$, Archana Singh ${ }^{2}$ \\ Assistant Professor, ${ }^{1}$ Dept. of Economics, ${ }^{2}$ Dept. of Decision Sciences, Birla Institute of Management Technology, Greater \\ Noida, Uttar Pradesh, India
}

*Corresponding Author:

Email: ritu.srivastava@bimtech.ac.in

\begin{abstract}
The recent development in the smartphone technologies and internet services lead to new development in the way e- government efforts to provide services to citizen. In this paper we present the initiatives taken by the government by launching mobile application for public welfare. This paper looks at the characteristics, constraints, limits and success of application since they have been launched. The focus is on analysing the level of success and to investigate consumer preferences and perception of these mobile applications. The results of the survey indicate high level of consumer satisfaction in terms of accessibility, comprehensibility and efficiency of process. However, the study points towards certain areas of improvement like regular updation and increasing the reach towards rural consumers.
\end{abstract}

Keywords: Government initiative, Mobile apps, Welfare, Review.

\section{Introduction}

A government initiative is essentially a Government step which is established to define and lay building blocks for a nationwide statutory function or project. With the notion of public welfare government of India has promoted digitalisation and made it way approachable by launching various mobile applications that can make public more aware, reasonable, approaching, secure, informative and many more in the light that government should be approachable and assessable by the common mass and its benefits must reach to the people. Public welfare is not only restricted to walls of social welfare, instead it has come out of the box in terms of mini but crucial steps taken up by government in order make lives more easy meanwhile maintaining healthy and deep rooted relationship with the common people which will not only benefit the public in common by having more say to government but also to government with overwhelming response of loyal public which will result in further growth of government which ensure growth of the nation. Government launches apps with agenda of public welfare but actually it turns out to be publicity propaganda on a larger scale. In general it puts lesser efforts to promote the apps and in providing access to those apps. Hence, the expected benefits do not fully reach the masses. Only certain apps launched by the government get successful because there exist no such alternative for that particular app and therefore, public in general becomes bound to use them namely IRCTC, RTI, PASSPORT SEVA, etc. These services come under the umbrella of government and no such alternative exists for the same and even if it does, it is paid or not relevant. Certain apps such as BHIM, INCREDIBLE INDIA etc. are identified as the area of research because they were launched in light of benefiting people in their respective areas but in reality they were not that very successful as compared to other apps launched by the government and the reasons of the same are the main concerns of the research.

\section{Literature Review}

A review was conducted on the literature using key search terms in several relevant journals. Articles published in last one decade were considered because after that only mobile phones and mobile applications were more in trend. Further inclusion and exclusion criteria were applied to the sample articles. For example: if the assessed app is supported with qualitative data only, it has not taken into consideration. Inukollu et. al.( 2014) have stated that about 6.4 billion applications were downloaded in 2009 as per the report "world mobile applications market - advanced technologies" by Global Forecast for the period 2010-2015. Rachel et. al.( 2013) have introduced a PACMAD model (People At the Centre of Mobile Application Development) which identifies user, task and context of use as factors influencing the overall usability of mobile applications. Zhang and Adipat (2005) have mentioned connectivity, small screen size, limited processing capability and power as device related issue which also affect the overall usability of mobile applications.

Srivastava (2014) has reported a number of findings in her article in an e-paper about the mobile app store launched in January 2012 that hosts more than 300 live and 62 demo apps. It compiles a list of apps from among these that provide citizen-centric services such as Right to information directory, Voter information search using SMS and internet, Rakshak, Hospital Tracker, in my vicinity, Sheltor, and mPassport Seva etc. for the user welfare. The study demonstrates that the government is preparing up in favour of using mobile phones and tablets to deliver information and services to citizens. 
An article print released by Press Information Bureau, Government of India (Ministry of Health and Family Welfare) on $7^{\text {th }}$ April 2016 stated that on the occasion of world health day, the Union Minister of Health and Family Welfare, Shri J P Nadda stated that "We need to focus on the youth and adolescents of the country in our efforts to prevent and combat lifestyles diseases such as Diabetes". Several e-health and mhealth initiatives like 'Swasth Bharat Mobile application', 'E-RaktKosh initiative', 'ANM Online application-ANMOL', and 'India Fights Dengue' were launched on that day. This article depicts that government of India is concerned about launching mobile apps in medical areas also.

\section{Research Objectives}

This section of research actively focuses on what mobile applications are actually trending in the market and what are the public responses for the same. Simultaneously it attempts to find out the government contribution in this field. The mobile applications launched by the government are from the view point of public welfare. This section focuses on whether public is actually being able to receive the requisite benefit for which the apps were launched. An online survey is conducted to collect information on the awareness and the outreach of government apps to the students pursuing post graduate management studies.

\section{Research Design}

The study was done using both primary and secondary data. Information from reviews of apps in various newspaper articles, play store review \& ratings was collected. Apps that were taken up for study were from different government ministries which were considered by the researcher as lacking in terms of outreach and connectivity. Keeping this objective in mind the research is done on existing facts and comparative study from the successful apps and the gap is tried to be highlighted. Primary data is collected by administering a questionnaire to the management students in the Knowledge Park with total number of respondents being hundred and thirty.

\section{Data Analysis and Results}

The results of the primary survey are presented below for further analysis. As per the survey the major apps launched by the government and public awareness and reaction towards their features, service quality and objectives of public welfare have been recorded. Around $43.3 \%$ of respondents were aware of five government mobile applications while only $20 \%$ of respondents had an awareness of more than five (Table 1). BHIM app and Passport Seva app were found to be the most known apps with $77.8 \%$ and $66.7 \%$ awareness levels (Table 2).

Table 1: Awareness of the mobile applications launched by Indian government

\begin{tabular}{|l|c|}
\hline $\begin{array}{c}\text { Number of mobile } \\
\text { applications }\end{array}$ & $\begin{array}{c}\text { Percentage of } \\
\text { respondents aware of } \\
\text { mobile apps }\end{array}$ \\
\hline 0 & 0 \\
\hline 2 & 36.7 \\
\hline 5 & 43.3 \\
\hline More than 5 & 20 \\
\hline
\end{tabular}

Table 2: Usability of selected mobile applications in percentage

\begin{tabular}{|l|c|}
\hline $\begin{array}{l}\text { Mobile } \\
\text { applications }\end{array}$ & $\begin{array}{l}\text { Percentage of } \\
\text { respondents who have } \\
\text { used the apps }\end{array}$ \\
\hline BHIM app & 77.8 \\
\hline Khoya Paya app & 0 \\
\hline RTI app & 25.9 \\
\hline Passport Seva app & 66.7 \\
\hline Incredible India App & 14.8 \\
\hline
\end{tabular}

The respondents were also inquired about the information regarding the ease of accessibility, ease of usage, concern of security and reliability and the onus taken by government in handling these public welfare mobile apps. On a 5 point likert scale, where each number is expressed as; 1-Very Poor, 2-Poor, 3Satisfied, 4-Good and 5-Excellent, 13 questions were framed so as to find out the perception of the end-users regarding these apps launched by the Government of India.

Table 3: Perception of consumer for mobile apps launched by Government of India

\begin{tabular}{|c|l|c|c|c|c|}
\hline & \multicolumn{4}{|c|}{ Descriptive Statistics } & $\begin{array}{c}\text { Std. } \\
\text { Deviation }\end{array}$ \\
\hline & \multicolumn{1}{|c|}{} & $\mathrm{N}$ & \multicolumn{2}{|c|}{ Mean } \\
\cline { 3 - 6 } & Statistic & Statistic & $\begin{array}{c}\text { Std. } \\
\text { Error }\end{array}$ & Statistic \\
\hline 1 & You find government apps useful & 130 & 3.50 & .239 & 1.180 \\
\hline 2 & You find government apps are regularly updated & 130 & 2.49 & .239 & 1.179 \\
\hline 3 & $\begin{array}{l}\text { You find government apps are paying benefits to } \\
\text { rural India }\end{array}$ & 130 & 2.53 & .253 & 1.239 \\
\hline 4 & $\begin{array}{l}\text { The app service is accessible at all time through } \\
\text { mobile device }\end{array}$ & 130 & 4.50 & .209 & 1.022 \\
\hline
\end{tabular}




\begin{tabular}{|c|l|c|c|c|c|}
\hline 5 & $\begin{array}{l}\text { The app service is accessible from anywhere through } \\
\text { mobile device }\end{array}$ & 130 & 4.16 & .195 & .955 \\
\hline 6 & The service is easy to search through mobile device & 130 & 3.74 & .289 & 1.414 \\
\hline 7 & $\begin{array}{l}\text { I can easily perform my task through my mobile } \\
\text { device }\end{array}$ & 130 & 4.42 & .255 & 1.238 \\
\hline 8 & $\begin{array}{l}\text { Instruction provided to process the service is } \\
\text { understandable through mobile device }\end{array}$ & 130 & 4.75 & .227 & 1.113 \\
\hline 9 & $\begin{array}{l}\text { Outcome of the service is understandable through } \\
\text { my mobile device. }\end{array}$ & 130 & 4.58 & .260 & 1.176 \\
\hline 10 & $\begin{array}{l}\text { Any transaction during conducting the service } \\
\text { through my mobile device is overall reliable. }\end{array}$ & 130 & 3.96 & .237 & 1.160 \\
\hline 11 & $\begin{array}{l}\text { Government takes responsibility for any technical } \\
\text { discrepancy during processing of the app service. }\end{array}$ & 130 & 3.25 & .264 & 1.294 \\
\hline 12 & $\begin{array}{l}\text { Outcome of the app service containing personal } \\
\text { identity and financial information is safe. }\end{array}$ & 130 & 3.28 & .294 & 1.442 \\
\hline 13 & $\begin{array}{l}\text { I am happy with the overall service offered through } \\
\text { the mobile app }\end{array}$ & 130 & 3.75 & .233 & 1.189 \\
\hline & Valid N (listwise) & 130 & & & \\
\hline
\end{tabular}

From the table 3, it is interpreted that a majority of the users are satisfied with accessibility of apps from anywhere and at all the times. Also they are contented with the performance of the task, instructions provided and outcome received through the mobile device. On the other hand, majority of the users don't feel that government apps are regularly updated and they don't think that rural India is reaping any benefits of these apps launched by the government of India. There is a mixed feeling about others aspects. The overall opinion about services offered through the mobile apps is between satisfied to good.

The five apps which are considered for this research study are as follows:

BHIM (Bharat Interface for Money) is a Mobile App developed by National Payments Corporation of India (NPCI), based on the Unified Payment Interface (UPI). It was launched by Narendra Modi, the Prime Minister of India, at a Digi Dhan mela post demonetisation on 30 December 2016.

The Narendra Modi government's pet digital payment projects - the mobile money transfer application BHIM and the Aadhaar-based merchant payment system BHIM-Aadhaar - needs rejigging and a more thoughtful implementation process in order to attract rural mass as well.

An internal examination made by the National Payments Corporation of India (NPCI), an open segment bank-controlled substance engaged with coasting and dealing with the instalment framework, has uncovered that poor awareness and a defective client encounter has brought about a high number of rural clients who have either erased the application or are idle.

In December 2016, Prime Minister Narendra Modi propelled an UPI-based portable application called
BHIM (Bharat Interface for Mobile) and asserted that the day isn't far when all business exchanges will be directed through the BHIM application.

But then, BHIM hasn't made it that far. Despite the fact that the application has seen about 20 million downloads, information demonstrates that under $30 \%$ of the general population who have downloaded the application have really connected the application to their financial balances and occupied with dynamic exchanges.

NPCI comprehends that BHIM hasn't generally taken off and the quantity of clients who have either erased the application or are dormant are high. One reason is absence of learning about how to utilize BHIM and, all the more essentially, why it ought to be utilized, what are its USPs contrasted with alternate modes they utilize. The issues begin with when clients begin opening the BHIM application. "It was watched that respondents felt bothered when they didn't promptly comprehend what undertaking should be performed at each screen, how it is to be performed, and if there was some blunder because of off base passage" (IANS, 2017)

Incredible India App is an inventive venture of Ministry of Tourism to help the global and local visitors to get data about government recognised tourism service providers viz. affirmed Inbound Tour Operators, Travel Agents, Tourist Transport Operators, Classified Hotels and endorsed Regional Level Tourist Guides accessible in the city or tourist destination. Points of interest are shared through this application to the vacationer on his/her cell phone/gadget based on his/her present location. This app was launched in September, 2014.

The app is simple to use and has a patriotic background design with saffron, white and green. All the information is available easily and it is also possible to place a call, email or add to contact list easily through 
the app. Users can also read about places of interest and then easily locate it, by just clicking 'Locate' which will then open the user's default browser and identify the place and provide other details.

While trying out the manual search function with all four of the categories, including places of interest, hotels, travel trades and guides selected, it failed to provide any details about a few cities and returned no results, while it worked fine for a few other cities. Since the app is quite new the options are limited to the popular cities and there is a scope for a lot more cities and towns to be added.

But with regards to its usage, the application isn't very excellent and frequently slacks. The UI is quite monotonous and renovation is needed for this app.

Khoya-Paya App is a citizen-centric application used for finding the missing children. The people don't have to wait for completing the legal formalities. Any person who is registered with the portal can provide information about a missing or sighted child. It has been developed by the Department of Electronics and Information Technology (DeitY) and the Ministry of Women and Child Development.

On paper, the site appears like a nice thought. Any parent whose child is missing can refresh data on this gateway which will be imparted to the cops and experts continuously. Anybody in the nation can likewise refresh data on any missing youngsters they know about. The 'Found' children can also be reported on this portal. The reporting can be done through videos, photographs, text, videos etc. In the majority of the cases, the groups of the missing kids are to a great degree poor and unskilled. Utilizing the Internet facility is not feasible for them. So they are unaware of such apps and are unable to utilize their benefits.

Passport Seva App: Riding on the new flood of data dispersal, Ministry of External Affairs has brought the travel permit related data on the versatile for cell phone clients. Clients would now be able to get to this data on their cell phones utilizing versatile application mPassport Seva. mPassport Seva is outlined fundamentally for the subjects who are keen on Passport related data as it were. It's a light weight, simple to utilize application that gives particular points of interest on territories, for example, Location of focuses, Fee, Application Status, Contact Information and other General Information. The application gives data on different advances required to get an identification related administration and where to bring if there should be an occurrence of questions or concerns. The clients can look for a Passport Seva Kendra (PSK) or District Passport Cell (DPC). Natives living abroad can discover significant data about the Missions/Posts abroad. For specific states and regions, the clients can look for Police Stations too. Charge Calculator highlight of the application empowers clients to discover the required expense in view of the administration and method of accommodation. The clients can track status of their international ID applications utilizing document number and date of birth. For dispatched travel permits, the conveyance status can likewise be followd.

India is moving towards eGovernance. If it is considered in quantifiable terms, Passport seva kendra were giving visa related administrations to 20-25,000 individuals for every prior day digitization.

Today, due to the launch of passport seva mobile application 50,000 individuals can be served. In this way, with digitization, twofold the general population can be deal within a day .Till 2011, we simply had 37 international ID workplaces to the extent reach is concerned. Today, we have 37 identification workplaces in addition to 100 Passport SevaKendra, so the span has expanded essentially and we now take into account 23 states and 64 urban communities crosswise over India.

Our entrance has gotten a huge reaction from the residents-government are getting more than 2 crore hits on our gateway every day. As far as versatile applications, mobile app are getting 15,000 hits for every day and as far as call focus (which bolsters 17 distinct dialects) it is getting just about 20,000 calls for every day. So also, SMSs being sent from the framework, similar to police check, international ID dispatch, and so on, are 35,000 every day.

These numbers would not have been conceivable without digitization and launch of the app. But there a huge number of people who is facing problems and are not satisfied with digitalized service. They find it difficult to use as many people experienced that the online way of form filling complicated than the traditional method. Also, too much of advertisement makes it irritating for the people to use it. And they are not happy with technical issues which the app has. Many people responded that they face issue while booking the schedule as due to heavy trafficking the slots get filled up online within no time.

RTI App: To help make the Right to Information (RTI) act much more open to nationals, RTI India has propelled a portable application for Android telephones. Accessible to download for nothing from the webpage www.rtiindia.org, the application functions as a cross between a long range interpersonal communication website and an RTI all-encompassing help book.

As per the findings "It essentially enables individuals from the site to get to all the data, gatherings and inquiries on their cell phones," says CJ Karira, who directs the online entrance www.rtiindia.org, which in a matter of four-odd years, has accumulated more than 2.25 lakh individuals and developing. The Android portable application will enable clients to send and get individual messages and post inquiries regarding the RTI follow up on different gatherings, aside from different administrations. For those intrigued by practicing their rights, for those keen on practicing their rights, it will likewise list all the data in regards to the state and local government rules.

Starting at now, just a modest bunch of individuals have downloaded the application, however it is trusted 
the number will develop when they start taking into account the various programming too. In any case, Nokia and Blackberry telephones won't fall in that class. "With every one of the applications out, we plan to cover no less than 75 percent of the market".

Appropriate to Information Act 2005 orders convenient reaction to native solicitations for government data. The RTI entryway is implied for fast pursuit of data on the points of interest of the principal investigative experts and PIOs among others, other than access to RTI related data or revelations distributed on the web by different open specialists under the administration of India and state governments.

Flooded number of complaints in regards to the RTI app functioning and slow response from the authorities makes it viable that though the success rate was expected to rise but the committed notion of serving people was not up to mark, also the awareness grounds were limited to urban boundaries only. It is nested with the ultimate benefit of RTI act which has to reach to the masses.

Play store ratings shows that the app is liked by people at the early launch but soon the over flooded RTI requests made it slow in response and so the interest of public shifted to big forum app that is must fast and user friendly in terms of login access and control which has resulted in more registered members than the interest app i.e. RTI App.

\section{Conclusion \& Discussion}

Government takes initiatives for betterment of public in general, but based on research data we can find that there exists a scope, for providing better access to people especially in rural areas because they are the once that are most deprived of the benefits of government initiatives. The National Mobile Governance Initiative by Ministry of Electronics \& Information Technology tells about the various multiple area and department related initiatives for mobile apps and the data is huge, so much the government of India has done for the people to promote digital India and to shape the digital face of the country as a whole. But still there exists certain gaps. As per our research most of the people are not properly aware about the initiatives at a large and also there is a flaw of less communication about the same and therefore the public response is low for certain apps and certain amount of people could not get benefited from the intended benefits. Another void that reflects the flash in the pan is delay in updating the apps regularly that are launched by government. To add to disparity found, too many ads pop up while using the certain government launched apps, and that creates hindrance and reduces the joy of using the app.

Based on the research the study suggests the noticeable improvements that can bridge the gaps between the intended purpose of the launching certain government apps as initiatives and there practical application, as well as their outreach to the common masses, including the one with least access to such initiatives.

Government along with taking such great initiatives, must also strive for reducing the gap mentioned in the analysis and findings section the abstract, so that the intended purposes of launching the apps i.e. "Public Welfare" must reach to the ones targeted and also greater involvement of people should be achieved which will bring much glory to the revolutionary initiative of government of India which is "Digital India", and it is the ultimate agenda that each corner of the country should be digitalised and corruption free, so that country would not only be counted as the developing nation but also climb the ladder and step in to the list of developed nations.

\section{References}

1. Harrison, R., Flood, D., \& Duce, D. 2013. Usability of mobile applications: literature review and rationale for a new usability model. Journal of Interaction Science, $1(1), 1$.

2. IANS, 2017. BHIM App Not Famous in Rural India, April 18, News 18.com. Accessed online http://www.news18.com/news/tech/bhim-app-notfamous-in-rural-india-1376895.html. Viewed on January 5, 2018.

3. Inukollu, V. N., Keshamoni, D. D., Kang, T., \& Inukollu, M. 2014. Factors influencing quality of mobile apps: Role of mobile app development life cycle. arXiv preprint arXiv:1410.4537.

4. Mallya, Harshith, 2014. [App Fridays] The Ministry of Tourism and its 'Incredible India' initiative, October 31, yourstory.com. Accessed online https://yourstory.com/2014/10/app-fridays-incredibleindia/. Viewed on February5, 2018.

5. Nadda, J. P.2016. Need to focus on the adolescents and youth for prevention of lifestyle diseases, April 07, Press Information Bureau, Government of India, Ministry of Health and Family Welfare. Accessed online http://pib.nic.in/newsite/PrintRelease. aspx?relid=1386 74. Viewed on February 3, 2018.

6. Srivas, Anuj, 2017. Modi's Digital Payment Push is struggling to Take Off in Rural India, Reveals Audit, September, The wire. Accessed online https://thewire.in/177642/narendra-modi-digital-indiaaadhaar-bhim-app/. Viewed on February 5, 2018.

7. Srivastava, Moulishree .2014.Developing citizencentric mobile apps, June 04, The department of electronics and information technology's Mobile Seva initiative provides citizens information on various services. Accessed online http://www.livemint.com/Industry/NjpHYN5ectJnfs0u FMi9sN/Developing-citizencentric-mobile-apps.html. Viewed on January 30, 2018.

8. Wilson, James, 2017. Did Demonetisation Bring About a Digital Transaction Revolution?, June, The wire. Accessed online https://thewire.in/152625/digitaltransactions-demonetisation-detailed-analysis/. Viewed on February 26, 2018.

9. Zhang, D, \& Adipat, B. 2005. Challenges, methodologies, and issues in the usability testing of mobile applications. International Journal of HumanComputer Interaction, 18(3), 293-308 